DOI:10.24193/tras.SI2018.7

Published First Online: 2018/12/28

\section{THE NEW MODEL FOR FILLING SENIOR POSITIONS IN THE CIVIL SERVICE IN POLAND}

\section{Ewa WÓJCICKA}

\section{Ewa WÓJCICKA}

Assistant Professor, Ph.D., Institute of Law, Administration and Management, Dlugosz University in Czestochowa, Poland

E-mail: e.wojcicka@ajd.czest.pl; ewa.wojcicka@poczta.fm

\title{
Abstract
}

The aim of this paper is to analyze the new model for filling senior positions in the civil service corps and to assess its compliance with the Constitution of the Republic of Poland. On January 23, 2016, under the provisions of the Act of December 30, 2015 amending the Act on Civil Service and some other acts, open and competitive recruitment for senior positions in the civil service was abolished and replaced by appointment. Simultaneously, the selection requirements have been lowered. The legislator revised the civil service career model by introducing elements of strict subordination and increasing arbitrariness in the processes of recruitment and termination of employment in senior positions. The new principles for filling senior positions in the civil service deserve critical assessment. The departure from open and competitive recruitment collides with the constitutional principles of professional, politically neutral and stable corps of civil service. The new model for filling senior positions does not guarantee an objective selection of the best candidate based on substantive criteria, and does not safeguard the professional status of the civil service corps.

Keywords: civil service, senior positions, government administration, Poland, politicization. 


\section{Introduction}

Civil service is one of the most important elements of government administration in Poland. Its shape is determined by the provisions of the Constitution of 1997, which require that members of the civil service corps to be professional, reliable, impartial and politically neutral. The legislator is supposed to base the model of civil service on those values and objectives. In the last 22 years, four acts on civil service have been passed (in 1996, 1999, 2006 and 2008) which regulated the shape and functioning of the service in different ways. The lack of legal and institutional continuity as well as frequent amendments to the regulations implies that no consensus has been reached on the final shape of the civil service. The binding Act on Civil Service of November 21, 2008 stipulates the following matters: organization of the service, establishment, changes and termination of the employment relationship, duties and entitlements of the civil service corps' members, training and development, and disciplinary liability. The act has been amended a number of times, e.g. by the Act of December 30, 2015 amending the Act on Civil Service and some other acts. Its entry into force on January 23, 2016 significantly changed the rules governing the civil service in Poland. The legislator revised the civil service career model by introducing elements of strict subordination and increasing arbitrariness in the processes of recruitment and termination of employment in senior positions. Simultaneously, the selection requirements have been lowered.

The aim of this paper is to analyze the new model for filling senior positions in the civil service corps and, in particular, to assess its compliance with the Constitution of the Republic of Poland. The thesis is that the change of employment rules in senior positions, i.e. the departure from open competitions for posts towards appointment-based employment, contradicts the constitutional values and objectives of the civil service, leads to politicization of the civil service and violates the citizens' right of access to public service.

\section{Methodology}

The primary aim of the article, that is an analysis and evaluation of the reform of filling senior positions in the civil service against constitutional standards, justifies the application of methods from the methodology of legal science. Therefore, the following methods have been used in the article: critical analysis of the literature, historical approach, dogmatic approach and comparative legal analysis. The method of critical analysis allowed for detailed consideration of the views presented in the literature. The historical approach allowed capturing the tendencies and the will of the legislator in the area of filling senior positions. The analysis covers not only the explanatory statements of acts and legislative works but also the decisions of the Constitutional Tribunal and the standpoints of the experts. The dogmatic method helped to reconstruct and systematize the shape of the civil service in Poland. The comparative legal analysis allowed reviewing and examining the models of recruitment for senior positions in the European countries and the trends in this area. The empirical method has 
also been used in the paper. In order to verify the adopted thesis, the study comprises a relevant literature review based on a number of sources, including the reports published by the Organization for Economic Co-operation and Development (OECD), Support for Improvement in Governance and Management (SIGMA), the European Commission, and the Head of the Civil Service (HCS) in Poland.

\section{Theoretical review}

\subsection{Constitutional and statutory grounds for civil service}

In Poland, civil service has been a constitutional institution since 1997. Pursuant to article 153 paragraph 1 of the Constitution of the Republic of Poland of April 2, 1997, the civil service corps functions in the government administration offices in order to provide professional, reliable, impartial and politically neutral performance of the state tasks. The corps is subordinated to the prime minister. The constitution introduced an obligation to establish civil service in government administration. Government administration offices, referred to in article 153 paragraph 1 of the Constitution, include administration offices that are organizationally and functionally subordinated to the Council of Ministers as a whole, the prime minister, individual ministers or voivodes (directly or through other bodies organizationally and functionally subordinated to these entities). An office can be considered a government administration office only if it performs tasks characteristic to the public administration in the area of public life where the state apparatus, led by the Council of Ministers, is present (Judgement of the Constitutional Tribunal of April 28, 1999). The Constitution does not stipulate detailed rules of recruitment to the civil service and its functioning, nor details about personal skills and professional qualifications of the corps' members; however, it precisely defines four basic objectives of the civil service.

Above all, members of the civil service corps should perform their tasks professionally and reliably. For this purpose, they should have appropriate qualifications and training (Judgement of the Constitutional Tribunal of December 12, 2002). Professional performance of the state tasks entails the necessity to employ persons who take up employment for profit and do not treat the civil service as a temporary job. Employment in the civil service should be a permanent source of income and provide competent persons with the opportunity to pursue a career (Judgement of the Constitutional Tribunal of November 13, 2003). Reliability means conscientious and reasonable performance of tasks, and performance of obligations in accordance with the law. It also involves efficient, timely and economical action, as well as rational management of public funds (Cieślak, Jagielski and Rączka, 2010, pp. 11-12). Another objective of the civil service is to perform tasks in an impartial manner, bearing in mind, above all, the interest of the state. It is also an obligation to remain impartial and free from pressure and personal views or sympathies when considering and settling interests of various entities (Jagielski and Rączka, 2010, p. 16). The premise of impartiality encompasses political neutrality that is the lack of influence of the political life on the activities of the civil service corps. To be more precise, it is 'the imperative of political 
neutrality in the performance of state tasks, especially the neutrality towards interests of political groups and disputes held by these groups or individual politicians' (Judgements of the Constitutional Tribunal of April 28, 1999 and April 10, 2002).

Professionalism, reliability, impartiality and political neutrality are the basic objectives and values which the legislator is to bear in mind while constructing a model of civil service. They were developed and specified in the Act of November 21, 2008 on civil service, which stipulates the shape and functioning of this service.

In Poland, the civil service corps is not uniform. Taking into account professional status, members of the civil service corps are divided into three categories: (1) civil servants employed under a contract of employment, (2) civil servants employed by nomination, and (3) persons employed in senior positions by appointment. The above diversity has a normative character, and is based on the criterion of establishing an employment relationship. There are significant differences between particular categories of the civil service corps' members as regards their professional status, especially between those employed under an employment contract or by nomination, and those holding senior positions. Their synthetic summary is presented in Table 1.

A special professional status is held by persons in senior positions, which include: (1) general directors of offices; (2) managers of departments or equivalent units in the Chancellery of the Prime Minister, offices of ministers, offices of chairmen of committees being part of the Council of Ministers, offices of central government administration bodies and departments or equivalent units in voivodeship offices, and their deputies; (3) voivodeship and poviat veterinarians, and their deputies; (4) managers of organizational units in the Bureau of Forest Seed Production, and their deputies; (5) director of the National Tax Information, directors of tax administration chambers, heads of tax offices, heads of tax and customs offices, and their deputies. Persons employed in the aforementioned positions should meet high qualification requirements and have personal predispositions and managerial abilities enabling them to efficiently and effectively perform their tasks. The key importance of the persons employed in these positions stems from the tasks they are to perform. They must ensure the proper functioning, organization and continuity of their offices, as well as efficient cooperation between the clerical and the political apparatuses, the latter of which is responsible for setting the government's policy (Judgement of the Supreme Court of January 13, 2010).

\subsection{An overview of recruitment models for the senior civil service in Europe}

Civil services are present in most European countries, although with different characteristics and peculiarities depending on particular needs, cultures and traditions of each state (Demmke and Moilanen, 2010; van Meer, Steen and Wille, 2015). In democratic countries, two main systems of employment in the civil service have been developed: career-based and position-based. The career-based model draws from Weber's bureaucracy and cultivates the tradition of a strong state apparatus. It points out that 'in this system high level civil servants share the same culture as 


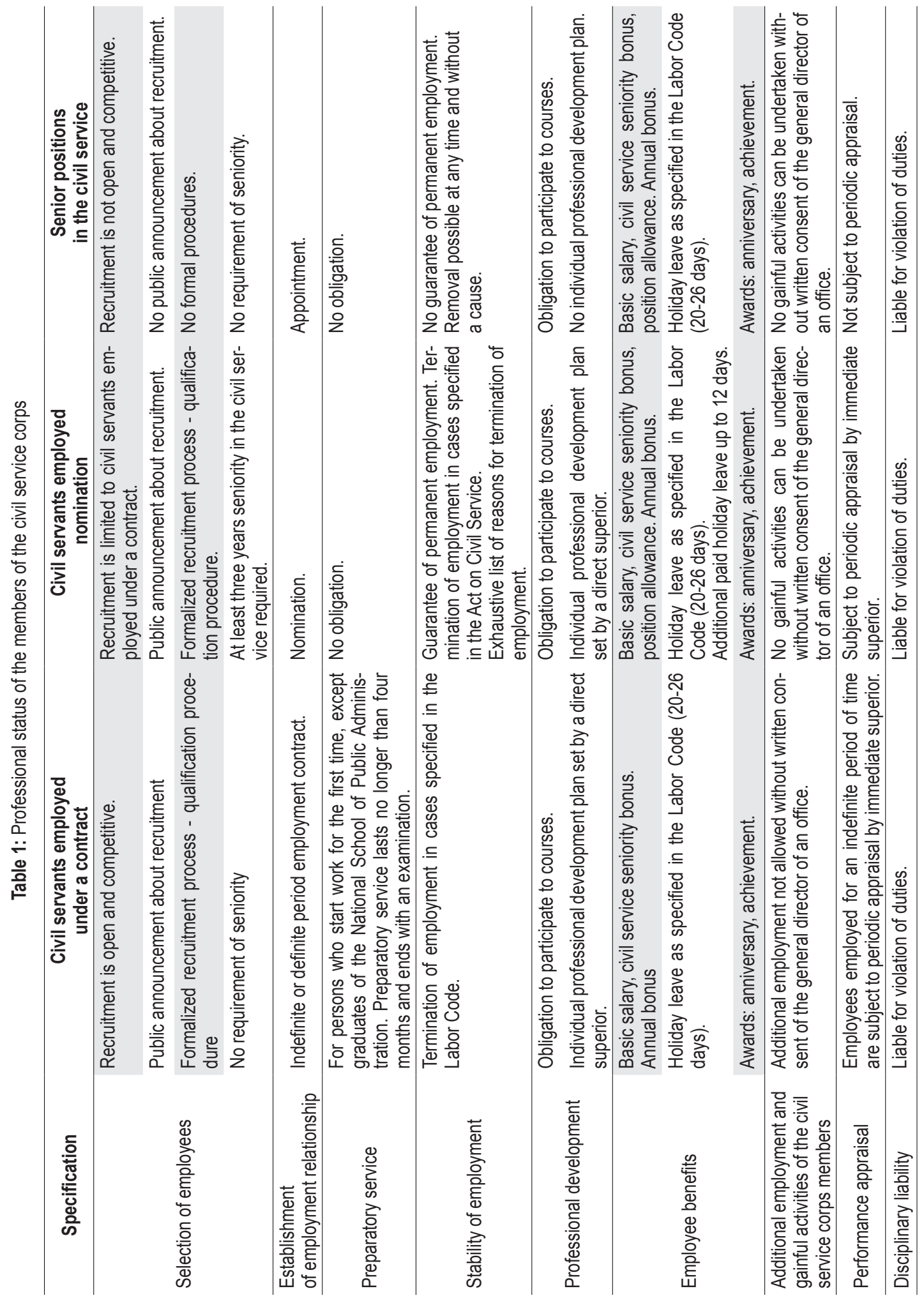


the rest of the staff, which makes working together and communication across government organizations easier and favors internal mobility' (OECD, 2008; Kuhlmann and Wollmann, 2014). Recruitment in the career-based employment system consists of regular examinations, which are designed to examine the general skills of candidates and to determine the best candidates for entering the civil service system. The position-based model drawing from the concept of new public management is client-oriented, and it is aimed at improving the quality of services. This system aims to provide a wider choice of candidates, including those with specialist skills. Recruitment consists of competition for vacant positions, and specific knowledge and skills are usually required for each individual position. Competition is open for everyone, not only for the employees of the civil service (Kuperus and Rode, 2008, p. 14).

With time, striving to develop a civil service model optimal for a given society, classic models began to be modified. This provided the basis for distinguishing mixed (hybrid) models, which are a combination of the elements derived from the Weber's bureaucracy concept and the elements from the position-based model. The studies carried out in 2016 by Kuperus and Rode (2016) show that the simple distinction between career-based and position-based systems is no longer sufficient. These researchers considered that the European recruitment systems should be divided into five categories: (1) mainly career-based system (Germany, Ireland, Greece, Spain, France, Cyprus, Luxembourg), (2) career hybrids: career system with some elements from the position-based system (Belgium, Italy, Hungary, Portugal, Romania), (3) real hybrids, where elements from both systems are really mixed in equal proportions (Croatia, Malta), (4) position hybrids: position-based system with some elements from a career system (Bulgaria, Denmark, Lithuania, Austria, Finland, Poland, Slovenia), and (5) mainly position-based system (Czech Republic, Estonia, Latvia, Netherlands, Sweden, United Kingdom).

Since 2008, it can be observed an overall trend towards position-based systems or at least a kind of convergence of these systems (Hammerschmid, Thijs and Palaric, 2017; Demmke and Moilanen, 2011). At present, for general civil servants, several countries still have a largely career-based system, but many of these, who had the original career-based systems (e.g. Belgium, Hungary, Portugal, Romania), have included elements of the position-based system (Kuperus and Rode, 2016, p. 13).

It should be noted that in many EU countries the recruitment procedure for senior positions differs from the general civil service employment system. This group of professional managers is normally referred to in the literature as the Senior Civil Service (SCS), but the designation varies from country to country and with the language used (Staroňová, 2016; Halligan, 2012). OECD has defined a Senior Civil Service as 'a system of personnel for high and top level management positions in the national civil service, formally or informally recognized by an authority, or through a common understanding of the organization of such a group, structured and recognized system of personnel for the higher non-political positions in government (Kuperus and Rode, 2008, p. 3). A different system of filling senior positions is connected with the fact 
that this group plays a crucial role in preparing and implementing public policies and in effectively delivering services to citizens (OECD/SIGMA, 2018, p. 23). They are also responsible for efficiency and appropriateness of the government activities (OECD, 2008, p. 68). Because their competency influences the achievement of the government's policy goals and trust in the government, most EU member states created different systems of recruitment for senior positions (Kuperus and Rode, 2016, p. 9). Thus we can identify: (1) career-based system (Germany), (2) career hybrids: career systems with some elements from the position-based system (Luxembourg, Greece, Romania), (3) real hybrids with a 50/50 mixture of elements from career- and position-based systems (Spain, France, Hungary), (4) position-based system with some elements from a career system (Belgium, Bulgaria, Croatia, Italy, Lithuania, Malta, Slovenia), and (5) mainly position-based system (Czech Republic, Estonia, Ireland, Cyprus, Latvia, Austria, Poland, Portugal, Slovakia, Finland, Sweden, Netherlands, United Kingdom).

In the past 10 years, there have been major changes in the models of recruitment for senior civil positions. At present only Germany has largely career-based system. Most of the countries have position-based system (14) or position-based system with some elements from a career system (7). Specialists indicate that the main reason behind this trend is the necessity to recruit top managers also from outside the civil service and to recruit based on relevant competencies and experience (Kuperus and Rode, 2016, p. 15).

However, it still points out that recruitment process must be based on equal treatment, which among other things implies a clear legal framework and the appointment of a selection committee free from political interference and composed of competent members. The above mentioned principle also requires the establishment of mechanisms that will prevent direct or indirect political influence on senior positions in the public service (OECD/SIGMA, 2017, pp. 43-46). Therefore, several member states (Belgium, Bulgaria, France, Greece, Hungary, Ireland, Italy, Lithuania, Romania, Slovakia and Spain) have a competition procedure or formal recruitment method, to provide that selection is based on merit, and fair and open competition. In the Netherlands, the recruitment system for senior positions is quite unique. The selection of candidates is performed through an open competition run by external private companies, independent of the administration. Even though there is no single procedure, researchers claim that 'the Dutch bureaucracy is characterized by political neutrality and technocratic specialization' (Kopińska, 2018, p. 12).

Most member states have some kind of body for recruiting or advising on the best candidates for senior civil service positions in order to ensure political neutrality and independence in the recruitment process of senior civil servants. In Austria, Cyprus, Denmark, Malta and the United Kingdom there is a body that advises the appointing authority on recruiting SCS. In Bulgaria, Estonia, Greece, Ireland, the Netherlands, Slovenia and Romania there is a permanent recruitment commission that organizes the competitions for SCS positions and reaches a decision on one or more of the most 
qualified candidates. In other states, senior civil servants' recruitment is facilitated by the respective National School of Public Administration (France, Italy and Spain) or by the Federal Selection and Recruitment Office (Belgium). In Hungary, Latvia, Lithuania, Portugal, Slovakia and Slovenia senior civil servants' recruitment is facilitated by a competition commission for individual vacancies (Kuperus and Rode, 2008, p. 14; Rossidis and Aspridis, 2017).

\subsection{The Polish model of filling senior positions and its reform}

Persons holding senior positions in the civil service are responsible for implementing the government's policy and ensuring smooth human resources management. Recruitment for these positions is of key importance in the construction of a modern state apparatus. The recruitment procedure should result in selection of the best candidates, professionals in their fields with aptitude for work in public administration. This can translate not only into a more efficient public administration but also into a positive image of the public administration (Mroczka, 2014, pp. 197-198).

Until January 22, 2016, the recruitment was conducted by a team composed of members of the civil service corps, whose knowledge and experience guaranteed the selection of the best candidates. The team selected no more than two best candidates who met the obligatory requirements and the desirable requirements to a greatest extent. In the event that none of the candidates met the requirements sufficiently well, the team did not make a selection. Openness and competitiveness were the basic principles governing the recruitment for senior positions in the civil service. The principle of openness meant common access, equality and transparency of the recruitment. It also guaranteed that anyone who met the requirements listed in an announcement could apply. The principle of competitiveness meant uniform rules, methods, tools, evaluation criteria and conditions for all candidates taking part in the recruitment. It also guaranteed that the requirements stipulated in a vacancy announcement would remain unchanged during all stages of the recruitment procedure (Stolarczyk, 2012, p. 9). According to the specialists, the then-existing mechanism for filling senior positions in the civil service was the most desirable, for it enabled the employment of objectively best candidates (Baran, 2014).

On January 23, 2016, under the provisions of the Act of December 30, 2015 amending the Act on Civil Service and some other acts, open and competitive recruitment for senior positions in the civil service was abolished and replaced by appointment. In the explanatory statement of the bill, it was pointed out that 'Application of the Act on civil service often results in prolonged and ineffective recruitment procedure, leading to delays in filling vacancies. Filling senior civil service positions by appointment [...] shall enable efficient employment of persons meeting the requirements for these positions stipulated in the Act on civil service and having education, skills and aptitude fitting the current needs of a given office' (Sejm, 2015). The persons authorized to appoint and dismiss persons holding senior positions in the civil service include competent ministers, heads of central administration offices, head of the Chancellery of the Prime 
Minister or voivodes, general directors of offices, Chief Veterinary Officer (in concert with the competent voivode) and director of the Bureau of Forest Seed Production.

Appointment is a special form of employment relationship due to its limited protection. It entails lesser permanence of employment, and the possibility to dismiss the appointed person at any time, immediately or at a specific date, even without giving the reason (Judgment of the Supreme Court of July 11, 2017). Thus, in practice, the person appointed to a senior position in the civil service is completely subordinated to the appointing authority.

Besides the departure from open and competitive recruitment, the legislator has significantly altered the qualification requirements to be met by persons holding senior positions in the civil service. A candidate for a senior position in the civil service must: (1) be a Polish citizen', (2) enjoy full public rights; (3) not have been validly convicted for intentional crime or intentional fiscal crime; (4) hold a master's degree or an equivalent degree; (5) not have been validly sentenced to a ban on holding managerial positions in offices of public authorities or performing functions related to the management of public funds; (6) have managerial competences; and (7) meet the requirements specified in the job description and separate regulations.

The provisions requiring candidates to prove their seniority and experience in performing managerial functions have been repealed. In the case of the general director of an office, it was at least six years seniority, including at least three years of managerial experience in units of the public finance sector. In the case of other senior positions, it was at least three years seniority, including at least one year of managerial experience or two years of experience in an independent position in units of the public finance sector. What is more, persons holding senior positions in the civil service have been excluded from the system of periodic appraisals and individual professional development plans.

\section{Assessment of the new regulations on filling senior positions}

The assessment of all modifications regarding the status and principles of the civil service functioning should be aimed at establishing whether public administration tasks can be performed in the way provided for in the Constitution. Taking the above into account, the aforementioned article 153 paragraph 1 of the Constitution is of paramount importance. Pursuant to its provisions, civil service is established in order to provide professional, reliable, impartial and politically neutral performance of the state's tasks. It is a core element of the entire government administration, and its institutional protection should be perceived as a constitutional value. The legislator's

1 The legislator allowed the possibility to employ persons who are not Polish citizens on positions selected by the general director of an office with the consent of the Head of the Civil Service, namely: (1) foreigners who are citizens of the European Union, and (2) foreigners who are citizens of other countries and are entitled to take up employment in Poland on the basis of international agreements or provisions of EU law. 
regulatory freedom as regards shaping the principles of recruitment, functioning, organization and status of the civil service is therefore limited by the objectives stipulated in the Constitution (Judgement of the Constitutional Tribunal of June 14, 2011).

If the civil service corps is to have the character specified in the Constitution, the recruitment procedure is crucially important. As the Constitutional Tribunal held in its judgement of December 12, 2002, recruitment procedure should be based on objective criteria and free from interference of the politicians or attempts to impose specific personnel decisions. This purpose was served by the open and competitive recruitment. As a result of the amendment, the legislator departed from those principles.

The new principles for filling senior positions in the civil service deserve critical assessment for several reasons. First of all, the new legal construct of appointing and dismissing persons holding senior positions does not guarantee political neutrality and stability of the civil service. The Constitutional Tribunal has repeatedly pointed out, among others in the judgement of June 16, 2003, that filling posts in the public service should be independent of political influence, as it is the basic and necessary condition for the political impartiality and competence of this service. The departure from open and competitive recruitment for senior positions in the civil service resulted in the employment based on particular interests of politicians. As a consequence, the civil service can be politicized, and its personnel policy can be controlled by the ruling party. As Gadowska (2009, p. 55) aptly noticed, 'if general directors of offices come from political appointments, there are justified fears that their decisions regarding the filling of lower positions in their offices will also have a political character. The politicization of senior positions creates the risk of spreading personnel manipulations to lower levels'.

The effect of the reform is the politicization of the senior civil service positions. Researchers who analyzed this process emphasized that the politicization of the civil service might have a number of negative consequences related to the quality of administration in the context of knowledge management and employees' motivation (Mazur, Możdżeń and Oramus, 2018, p. 80; Goetz and Wollman, 2001). A high level of politicization makes the officials be more loyal to their superior than to the principles of legalism and the rule of law, which undermines the principle of professionalism, results in inferior-quality public service provision, and a loss of trust in the administration (Peters and Pierre, 2004, p. 9; Mazur, Możdżeń and Oramus, 2018, p. 80).

Another controversial change is the lowering of the recruitment criteria. If the state tasks are to be performed professionally, civil servants, particularly those in senior positions, ought to have some specific qualifications. Those qualifications should be verified with respect to reliable performance of duties before one becomes a member of the civil service corps and later in the course of service (Judgement of the Constitutional Tribunal of December 12, 2002). Therefore, the departure from the requirements of seniority and managerial experience for senior positions in the civil service, and the exclusion of persons holding such positions from performance appraisals should be assessed negatively. This mechanism cannot help to achieve the constitu- 
tional objectives regarding the civil service, i.e. professional and reliable fulfilment of the state tasks.

Attention should also be paid to the lack of employment stability in the case of persons holding senior positions in the civil service. Special protection of their employment status is necessary not because of protection of their personal rights but because of protection of the public interest. The underlying aim of employment stability in the civil service is to guarantee citizens the right to good administration. The protection of employment relationship is to provide the state institutions with an adequate number of highly qualified employees and consequently better and more effective performance of the state tasks. The stability of the employment allows for filling positions independently of political criteria, which is the prerequisite for political neutrality and competence of the civil service. Owing to the protection of employment permanence, civil servants are not concerned about their professional future and can concentrate on performing duties for the good of the state not being involved in political power struggles (Baran, 2014). This view is reflected in the judgement of the Constitutional Tribunal of June 16, 2003, which stated that 'protection of the permanence of employment relationship, consisting primarily in the statutory regulation of circumstances enabling termination of employment, is to guarantee the possibility to perform statutory duties in a manner free from any external pressures'.

In comparison to the employment contract, election and nomination, employment by appointment is characterized by the least legal protection. The provisions of the Labor Code on termination of the employment, adjudication on ineffectiveness of termination or reinstatement do not apply to the persons employed by appointment (Judgement of the Supreme Court of December 2, 2009). The lack of sense of legal security and fear of being dismissed due to 'rationalization' or another equally general cause are certainly not conducive to impartiality and political neutrality. Undermining the status of this civil service elite, representing no more than $3 \%$ of the entire civil service, is incompatible with the constitutional objectives of the civil service. It jeopardizes the efficient functioning of government administration and the right of the citizens to good administration.

The legislator justified the elimination of open and competitive recruitment by the actual human resources situation in the government administration. The average employment in the civil service corps by positions is presented in Table 2 .

Table 2: Average employment in the civil service corps by position between 2009 and 2017

\begin{tabular}{lccccccccc}
\hline \multicolumn{1}{c}{ Specification } & $\mathbf{2 0 0 9}$ & $\mathbf{2 0 1 0}$ & $\mathbf{2 0 1 1}$ & $\mathbf{2 0 1 2}$ & $\mathbf{2 0 1 3}$ & $\mathbf{2 0 1 4}$ & $\mathbf{2 0 1 5}$ & $\mathbf{2 0 1 6}$ & $\mathbf{2 0 1 7}$ \\
\hline $\begin{array}{l}\text { Civil service corps } \\
\text { in general, including: }\end{array}$ & 120,908 & 122,989 & 122,842 & 121,541 & 121,376 & 120,412 & 119,257 & 118,848 & 119,382 \\
Senior positions & 1,475 & 1,540 & 1,607 & 1,557 & 1,574 & 1,582 & 1,588 & 2,103 & 3,197 \\
\hline
\end{tabular}

Source: The Chancellery of the Prime Minister (2018)

Between 2011 and 2016, a steady decline in employment can be observed. It resulted mainly from the reorganization of the structure of offices (e.g., dissolution 
of regional offices of the Ministry of Treasury; reorganization of tax administration carried out in 2015, which consisted in consolidation of tax administration chambers and offices; transferring the employees of the Ministry of National Education and the Ministry of Science and Higher Education responsible for the implementation of projects financed from EU funds outside the civil service), as well as employment rationalization (e.g., in the Ministry of Foreign Affairs and the Ministry of Transport, Construction and Maritime Economy). The decline of employment was also affected by natural fluctuations (e.g., retirement) and the non-renewal of expiring fixedterm employment contracts (The Chancellery of the Prime Minister, 2016). Despite the growing number of new tasks, such as, inter alia, development of the emergency communication system or implementation and operation of the automatic traffic monitoring system, employment in the civil service decreased by $1.3 \%$ in comparison to 2009 (The Chancellery of the Prime Minister, 2018).

Between 2009 and 2015, the average employment in senior positions remained at a similar level $(1,500)$. In the year of the reform (2015), employment in senior positions amounted to 1,588 full-time positions (The Chancellery of the Prime Minister, 2016). In 2016 and 2017, employment increased by 515 and 1,094 positions respectively. The increase in employment in 2017 by as much as $52.0 \%$ was not the result of new admissions to the civil service, but organizational changes (The Chancellery of the Prime Minister, 2018). Pursuant to the Act of November 16, 2016 on the National Revenue Administration (Journal of Laws of 2016, item 1947), consolidated administration was established, merging tax administration, Customs Service and fiscal control and the positions of the heads of tax administration offices became senior positions of the civil service.

One negative effect of the reform is a considerable increase in the employment fluctuation. At the beginning of 2016, almost one-third (505 out of 1,588 of those employed as of January 22, 2016) of the senior civil service officials resigned from their posts or were transferred to other positions. Moreover, 212 employment contracts, i.e. over $13 \%$ of the total, expired and 293 persons (19\%) were transferred to lower positions in the civil service. In the same time, 1,255 people were appointed to senior positions, including 131 from outside the civil service (Mazur, Możdżeń and Oramus, 2018; Kopińska, 2018). In 2017, 744 people were dismissed from senior positions in the civil service, whereas 1,622 were appointed, including the newly created positions in the National Revenue Administration. In 2017, the fluctuation rate amounted to 11\%, which represents an increase by more than half comparatively with 2015. Specialists agreed that the situation was a result of the reform eliminating competitive recruitment, and made it possible to dismiss persons holding senior positions (Izdebski, 2016; Kopińska, 2018, p. 33). This state of affairs in the long term may be worrying. The high fluctuation rate may have a negative impact on the development of professional civil service responsible for implementation of the most important state tasks. It may also negatively influence task efficiency of the service.

Authors of the amendment argued that the departure from competitions for senior positions was solely due to the shortage of such employees. In 2013, an average 
of 7.7 candidates applied for one position, in $2014-6.5$, while in 2015 - 6.7. We cannot accept the opinion expressed by Gintowt-Jankowicz $(2015$, p. 6$)$ that 'competition between several candidates deprives this procedure of the character of competition and in fact is a fiction, for many reasons wasteful (time of recruiters, cost of tests, lengthiness of recruitment for important positions)'.

Both academics and practitioners agree that the selection systems have to be on competitive basis and be attractive enough for selecting the best candidates (Staroňová, 2016, p. 43). That is why the competitive recruitment for public positions is considered the most appropriate way of filling public positions in many countries, as it increases the probability of employing the most competent and honest person (Kopińska, 2018, p. 28).

It should be emphasized that the low interest in civil service careers is not caused by the necessity of going through the recruitment procedure, but low salaries and the lack of incentive schemes. Between 2009 and 2017, the remuneration in the civil service corps increased by $11.0 \%$ in real terms and by $22.2 \%$ in the national economy (The Chancellery of the Prime Minister, 2018). The problem of low earnings also applies to specialist positions that require high qualifications and continuous improvement of competences. As a consequence, there is little interest in the civil service as a workplace, and so is the number of candidates for civil servants.

The unsatisfactory staffing situation and the lack of interest in working for the civil service cannot justify such far-reaching deviations from the rules. Even if there is a personnel shortage, competition should be mandatory, for it is the basic instrument ensuring the implementation of constitutional requirements. The introduction of such a far-reaching exception regarding the recruitment for senior positions undermines the purpose of the institution of civil service.

The new model of recruitment for senior positions should be criticized for one more reason. By introducing arbitrariness into the recruitment for senior positions in the civil service, the legislator limited the right of citizens to information about such vacancies (article 6 of the Act on Civil Service). In the new recruitment model, information about vacant job positions in the government administration is not made public, which is against the provisions of the article 60 of the Constitution of the Republic of Poland. Pursuant to that article, citizens have the right to equal access to public service, meaning that the same recruitment rules should apply to everyone. The obligation to respect identical rules by everyone determines the transparency of the civil service recruitment criteria (Judgment of the Constitutional Tribunal of May 10, 2000). Yet, there is hardly any equality in the access to the civil service since this right can be exercised only by those who have the exclusive knowledge about vacant senior positions. What is more, this change is in contradiction with international standards, including article 25 of the International Covenant on Civil and Political Rights ratified by Poland in 1977. It provides that every citizen has the right and the opportunity, without any discrimination and unreasonable restrictions, to have access to public service in their country on general terms of equality. This principle was 
also reflected in the recommendation of the Committee of Ministers of the Council of Europe no. R(2000)6 of February 24, 2000 on the status of public officials in Europe, laying down recruitment standards for public service, which should be pursued by the member states. In light of this document, recruitment for public service should comply with the principle of equal access to this service. The procedure should be open, competitive and based on substantive criteria.

\section{Conclusions}

The civil service corps of government administration was established to provide professional, reliable, impartial and politically neutral performance of the state tasks. In order to attain these objectives, an appropriate statutory mechanism is necessary, which ensures performance of such tasks by properly prepared officials. If the civil service corps is to be what the Constitution stipulates, the recruitment procedure is of paramount importance. The recruitment should be conducted in a transparent manner, based on objective criteria and aimed at selecting candidates that are best prepared to perform the tasks of government administration. Therefore, the general principle was established that the recruitment procedure for vacancies in the civil service corps should be open, competitive and publicly announced.

On January 23, 2016 the above principles ceased to be applied in recruitment for senior civil service positions. The amendment eliminated open and competitive recruitment for such positions. It is also not necessary for the candidates to have any professional experience. At the same time, the principle of full disposal was introduced with the effect that the dismissal of such persons can take place at any time, like the appointment. The new recruitment rules concern a small group of employees - in 2017 the number of senior positions did not exceed 3\% of the total number of civil service employees. However, it should be borne in mind that those positions are particularly important for the implementation of state tasks. In fact they occupy the highest place in the hierarchy of administrative positions. For these reasons, the new model for filling senior positions should be assessed negatively.

The civil service in Europe does not follow a single universal model for all the states. On the contrary, there are many different solutions, which stem from different traditions and constitutional factors. Starting from 2008, some changes in the model of recruitment for civil service positions have been observed in the EU member states, especially regarding senior positions - different selection procedures have been introduced for senior civil servants to obtain more experienced and efficient management staff. Most of the member states have a position-based system or position-based systems with some elements of a career system due to the necessity to recruit senior civil servants based on their ability to perform a job. Fukuyama (2014) claims that the merit-based recruitment system is a cornerstone of a well-functioning and professional public administration, ensuring good governance and administrative capacity.

The Polish legislator has quite a lot of freedom in shaping the legal status of the civil service, though that freedom is limited by the constitutional regulations. The 
departure from open and competitive recruitment collides with the constitutional principles of professional, politically neutral and stable corps of civil service. The new model for filling senior positions does not guarantee an objective selection of the best candidate based on substantive criteria, and does not safeguard the professional status of the civil service corps. It also does not guarantee civil servants the sense of stability indispensable for proper fulfilment of the state tasks. The fact of being appointed and the possibility of being dismissed makes it difficult for persons holding senior positions to perform the state tasks in a politically neutral manner. One should agree with Izdebski (2016) that the adopted solutions 'constitute (...) negation of constitutional and international standards of the civil service, and even negation of the very idea of the civil service'.

All things considered, the access to posts in public service through open and competitive recruitment conducted on the basis of clear statutory criteria should be a rule. Competition for senior positions in the civil service is the prerequisite of professional, reliable, impartial and politically neutral performance of the state tasks. Such a solution meets the requirements of justice as it eliminates arbitrariness of decisions. Most importantly, however, it allows the recruitment of the best candidates, which is how the citizen's right to good public administration can be fulfilled.

\section{References:}

1. Baran, K.W. (ed.), 'Komentarz do ustawy o służbie cywilnej' (Commentary to the Act on Civil Service), LEX/el. 2014.

2. Cieślak, Z., Jagielski, J. and Rączka, K., 'Komentarz do ustawy o służbie cywilnej' (Commentary to the Act on Civil Service), Warsaw: PWN, 2001.

3. Demmke, C. and Moilanen T., Civil Services in the EU of 27: Reform Outcomes and the Future of the Civil Service, Frankfurt: Peter Lang GmbH, 2010.

4. Demmke, Ch. and Moilanen, T., 'Effectiveness of Good Governance and Ethics in Central Administration: Evaluating Reform Outcomes in the Context of the Financial Crisis', Maastricht: European Institute of Public Administration, 2011, [Online] available at https://dsc.kprm.gov.pl/sites/default/files/pliki/ethics_report_final.pdf, accessed on December 1, 2018.

5. Fukuyama, F., Political Order and Political Decay: From the Industrial Revolution to the Globalization of Democracy, New York: Farrar, Straus and Giroux, 2014.

6. Gadowska, K., 'Działania pozorne. Problem upolitycznienia procesu obsady wyższych stanowisk w służbie cywilnej w Polsce' (Apparent Actions. The Problem of the Politicization of the Process of Staffing the Higher Clerical Positions in the Polish Civil Service), 2009, Przeglad Socjologiczny, vol. 58, no. 1, pp. 51-90.

7. Gintowt-Jankowicz, M., ‘Opinia prawna o projekcie ustawy o zmianie ustawy o służbie cywilnej oraz niektórych innych ustaw. Druk sejmowy nr 119 z 15 grudnia 2015' (Opinion on the Bill Amending the Act on Civil Service and Some Other Acts. Parliamentary Paper no. 119 of December 15, 2015), Warsaw, December 28, 2015, [Online] available at http://orka.sejm.gov/rexdomk8.nsf/Opdodr?OpenPage\&nr=119, accessed on July 1, 2018. 
8. Goetz, K.H. and Wollmann, H., 'Governmentalizing Central Executives in Postcommunist Europe: A Four-Country Comparison', 2001, Journal of European Public Policy, vol. 8, no. 6, pp. 864-887.

9. Halligan, J., 'Leadership and the Senior Civil Service from a Comparative Perspective', in Peters, B.G. and Pierre, J. (eds.), The Handbook of Public Administration, London: Sage Publications, 2012, pp. 98-108.

10. Hammerschmid, G., Thijs, N. and Palaric, E., 'A Comparative Overview of Public Administration Characteristics and Performance in EU28', European Commission, Brussels, 2017, [Online] available at ec.europa.eu/social/BlobServlet?docId=19208\&lang Id=en, accessed on July 2, 2018.

11. Izdebski, H., ‘Opinia w przedmiocie ustawy z dnia 30 grudnia 2015 r. o zmianie Ustawy o służbie cywilnej oraz niektórych innych ustaw (Dz.U. z 2016 r. poz. 34)' (Opinion on the Act of December 30, 2015 amending the Act on the Civil Service and Certain Other Acts), Warsaw, February 3, 2016, [Online] available at http://www.batory.org. pl/upload/files/Programy\%20operacyjne/Odpowiedzialne\%20Panstwo/Opinia_Sluz ba_cywilna_HIzdebski.pdf, accessed on December 1, 2018.

12. Jagielski, J. and Rączka, K., Ustawa o stużbie cywilnej. Komentarz (Act on Civil Service. Commentary), Warsaw: PWN, 2010.

13. Kopińska, G., Stanowiska publiczne jako tup polityczny (Public Positions as a Political Loot), Warsaw: Fundacja im. Stefana Batorego, 2018.

14. Kuhlmann, S. and Wollmann, H., Introduction to Comparative Public Administration: Administrative Systems and Reform in Europe, Cheltenham: Edward Elgar Publishing, 2014.

15. Kuperus, H. and Rode, A., 'Top Public Managers in Europe. Management and Working Conditions of the Senior Civil Servants in European Union Member States', Maastricht: European Institute of Public Administration, 2008, [Online] available at https:// dsc.kprm.gov.pl/sites/default/files/2_study_on_senior_civil_service.pdf, accessed on July 2, 2018.

16. Kuperus, H. and Rode, A., 'Top Public Managers in Europe: Management and Employment in Central Public Administration', The Hague: Ministry of the Interior and Kingdom Relations, 2016, [Online] available at http://www.eupan.eu/files/reposito ry/20170206084104_TopPublicManagersinEuropemainreport.pdf, accessed on July 2, 2018.

17. Mazur, S., Możdżeń, M. and Oramus, M., 'The Instrumental and Ideological Politicisation of Senior Positions in Poland's Civil Service and Its Selected Consequences', 2018, The NISPAcee Journal of Public Administration and Policy, vol. 11, no. 1, pp. 63-84.

18. Mroczka, K.S., 'Wpływ polityki zarządzania zasobami ludzkimi w polskiej służbie cywilnej na funkcjonowanie państwa' ('The Impact of Human Resources Management Policy in the Polish Civil Service on the Functioning of the State'), PhD thesis, Warsaw, 2014.

19. OECD, 'The State of the Public Service', Paris: OECD Publishing, 2008.

20. OECD/SIGMA, 'Analysis of the Professionalisation of the Senior Civil Service and the Way Forward for the Western Balkans', SIGMA Papers, No. 55, Paris: OECD Publishing, 2018.

21. OECD/SIGMA, 'The Principles of Public Administration', 2017, [Online] available at http://www.sigmaweb.org/publications/Principles-of-Public-Administration_Edition2017_ENG.pdf accessed on December 1, 2018. 
22. Peters, B.G. and Pierre, J., 'Politicization of the Civil Service: Concepts, Causes, Consequences', in Peters, B.G. and Pierre, J. (eds.), Politicization of the Civil Service in Comparative Perspective. The Quest for Control, New York: Routledge, 2004, pp. 1-13.

23. Rossidis, I. and Aspridis, G., 'Comparative Analysis of Recruitment Systems in the Public Sector in Greece and Europe: Trends and Outlook for Staff Selection Systems in the Greek Public Sector', 2017, Academic Journal of Interdisciplinary Studies, vol. 6, no. 1, pp. 21-30.

24. Sejm (Lower House of Polish Parliament), 'Poselski projekt ustawy o zmianie ustawy o służbie cywilnej oraz niektórych innych ustaw' (Explanatory Statement of the Bill Amending the Act on Civil Service and Some Other Acts), Parliamentary paper no. 119, December 15, 2015, [Online] available at http://www.sejm.gov.pl/sejm8.nsf/druk. xsp?nr=119, accessed on July 1, 2018.

25. Staroňová, K., 'Civil Service Reform in Slovakia', Bratislava: Vydavatel'stvo Univerzity Komenského, 2016, [Online] available at https://fses.uniba.sk/fileadmin/fsev/uvp/do kumenty_2015_16/Skripta_Civil_Service.pdf, accessed on July 3, 2018.

26. Stolarczyk, B., 'Nabór pracowników w służbie cywilnej' (Recruitment of Employees in the Civil Service), in Stolarczyk, B., Praktyczne aspekty zarzadzania zasobami ludzkimi w stużbie cywilnej. Poradnik (Practical Aspects of Human Resources Management in the Civil Service. The Guidebook), Warsaw: Edukator Film, 2012.

27. The Chancellery of the Prime Minister, 'Sprawozdanie Szefa Służby Cywilnej o stanie służby cywilnej i realizacji zadań tej służby w 2017 roku' (Report of the Head of the Civil Service on the state of the civil service and the implementation of the tasks of this service in 2017), Warsaw, 2018.

28. The Chancellery of the Prime Minister, 'Sprawozdanie Szefa Służby Cywilnej o stanie służby cywilnej i realizacji zadań tej służby w 2015 roku' (Report of the Head of the Civil Service (HCS) on the state of the civil service and the implementation of the tasks of this service in 2015), Warsaw, 2016.

29. van der Meer, F.M., Steen, T. and Wille, A., 'Civil Service Systems in Western Europe: A Comparative Analysis', in van der Meer, F.M., Raadschelders, J. and Toonen, T. (eds.), Comparative Civil Service Systems in the 21st Century, London: Palgrave Macmillan, 2015, pp. 38-56.

\section{Law and jurisprudence:}

30. Act of April 2, 1997 Constitution of the Republic of Poland, published in the Journal of Laws no. 78, item 483, as amended.

31. Act of November 21, 2008 on Civil Service, published in the Journal of Laws no. 227, item 1505, as amended.

32. Act of December 30, 2015 amending the Act on Civil Service and some other acts, published in the Journal of Laws 2016, item 34.

33. Judgement of the Constitutional Tribunal of December 12, 2002, K 9/02, OTK-A 2002, no. 7 , item 94 .

34. Judgement of the Constitutional Tribunal of November 13, 2003, K 51/02, OTK-A 2003, no. 8 , item 86 .

35. Judgement of the Constitutional Tribunal of June 14, 2011, Kp 1/11, OTK-A 2011, no. 5 , item 41 . 
36. Judgement of the Constitutional Tribunal of April 10, 2002, K 26/00, OTK-A 2002, no. 2, item 18.

37. Judgement of the Constitutional Tribunal of June 16, 2003, K 52/02, OTK-A 2003, no. 6, item 54 .

38. Judgement of the Constitutional Tribunal of April 28, 1999, K 3/99, OTK 1999, no. 4, item 73.

39. Judgement of the Supreme Court of January 13, 2010, II PK 175/09, LEX no. 821142.

40. Judgement of the Supreme Court of December 2, 2009, I PK 112/09, LEX no. 577682.

41. Judgment of the Constitutional Tribunal of May 10, 2000, K 21/99, OTK 2000, no. 4, item 109.

42. Judgment of the Supreme Court of July 11, 2017, I PK 201/16, LEX no. 2397620. 